\title{
SUSTAINABILITY OF MALAY WOOD CRAFTSMANSHIP SYMBOLISM IN DECIPHERING MALAYSIA'S ARCHITECTURAL IDENTITY
}

\author{
Aida Kesuma Azmin ${ }^{1 \star}$, Fadzidah Abdullah ${ }^{2}$, Aliyah Nur Zafirah Sanusi ${ }^{3}$, Zeenat \\ Begam Yusof ${ }^{4}$, and Nayeem Asif ${ }^{5}$ \\ ${ }^{1}$ Asst. Prof. Dr Aida Kesuma Azmin, IIUM, MALAYSIA, aida kesuma@iium.edu.my \\ ${ }^{2}$ Assoc Prof. Dr Fadzidah Abdullah, IIUM, MALAYSIA, fadzidah@ilum.edu.my \\ ${ }^{3}$ Asst. Prof. Dr Aliyah Nur Zafirah Sanusi, IIUM, MALAYSIA, aliyah@iium.edu.my \\ ${ }^{4}$ Asst. Prof. Dr Zeenat Begam Yusof, IIUM, MALAYSIA, zeensoni@iium.edu.my \\ ${ }^{5}$ Asst. Prof. Dr Nayeem Asif, IIUM, MALAYSIA, nayeem@iium.edu.my \\ ${ }^{*}$ Corresponding author
}

\begin{abstract}
Traditional Malay architecture symbolizes the manifestation of Malaysia's indigenous cultural heritage throughout centuries. Unfortunately, many elements of the architecture are depleting fast, due to improper maintenance, and the demise of Malay woodcarver artisans. Studies have shown that the issue of nonexistence of cultural meanings in contemporary housing is due to global proficiency, profit-making, and insensitivity of Western architecture compared to the traditional architecture. Worse, some developers in Malaysia claims generic wood craftsmanship in local housing designs as traditional Malay craftsmanship, which in truth do not belong to a certain region, nor portraying a reflection of the owner's personality. Wood, as a spiritual building material in traditional Malay houses are symbolically represented by its wood carving's artistry, which contain embedded values of principles, supremacy, hierarchy, religiousness, and versatility of its owners. Therefore, this study aims to establish the notions of Malay wood craftsmanship symbolism in deciphering traditional Malay's architectural Identity. The craft deserves to be regenerated and adopted into the contemporary buildings in order to maintain Malaysia's traditional architectural identity. Hence, the study's objectives are to elucidate the variants of wood carvings' functions in traditional Malay houses, to determine its symbolic meanings based on culture and religious influences; and identify the future challenges and opportunities for its sustainability. This study adopts qualitative methodology, such as case studies, indepth interviews, observation, and reviews of measured drawings from KALAM center, UTM. Apart from the wood carving motifs' physical function as natural ventilator, daylighting device, structural, decorative design elements, the findings discover some symbolic and cosmological meanings, which are closely related to God's creations such as flora and fauna; the cosmos, including the sun, moon and stars; journey to eternal life, and Islamic beliefs. The findings also identify few challenges and opportunities that include the lack of interest and knowledge, and loss of identity due to architectural globalism. There is still some opportunities to revitalize traditional Malay craftsmanship in contemporary Malaysian housing. This study will rejuvenate the forgotten Malay inheritance to be imbued in contemporary housing in Malaysia.
\end{abstract}

Keywords: Malay Wood Craftsmanship Symbolism, Sustainable Building Material, Wood Spirit, Architectural Identity. 


\section{INTRODUCTION}

The paper aims to establish the notions of Malay Wood craftsmanship symbolism in deciphering traditional Malay's architectural Identity. The woodcarving, as a decorative component of an architectural style, is possessed by the Malay artisans. Timber resources suitable for carving vary from the bush, orchard and compounds of the house. From the wood carver's perspective, wood is classified into three types according to the hardness and delicacy of the wood grain veins that are hard, semi-hard and soft. Malaysian Forest research Institute also has similar classification, such as Damar species that is both hard and semi-hard wood,, including Balau, Cengal Damar Hitam, Giam, Kapur and Keladan, These are the commercial species for building and small boat (perahu) constructions. Until now, the wood carvers in Besut, Kuala Terengganua and Kota Bahru, Kelantan, have chosen Cengal wood for the carvings of house components including door leaves, kekisi (lattices), wind comb and tunjuk langit (roof finial).

In the world of architecture and the built environment, man's interaction with nature can be recognised through symbolic representations of the arts and crafts. The traditional Malay society has indeed had a very deep attachment to nature in daily interactions between the community and the environment. Among others, the famous arts and crafts in Malaysia are the 'awan larat', 'batik' and 'songket', the woven mats, Islamic calligraphy and (metal) silver works.

\section{LITERATURE REVIEW.S}

This section defines the philosophical background of Malay woodcarvings craftsmanship and symbolic significance in the traditional Malay dwelling architecture as a cultural and local identity.

\subsection{Definition of Malay Wood carvings Craftsmanship Symbolic Influences}

The Malay woodcarving, (also known as, curvilinear fretwork) specifically in dwelling architecture is a carving design based on flora (plants) that has principles and a specific philosophy, that its shape is chained beginning from one point and developed until it fills the space. The late Wanpo explained that the specific philosophy means the messages or positive advice about the Malay community's culture as well as the Malay belief about the concept of God, i.e. the hidden message behind the principles of 'Awan larat' (Azmin, A.K., 2007), Plus, there are also clear and hidden messages that can be found from Quranic verses from the calligraphy art.

\subsubsection{The Wood carvings' Cultural and Religious influences}

"Architecture is something that is related to culture. For those buildings not referring to culture, it cannot be called, "architecture"; it is just merely a building". (Spiro Kostof, 1977)

\section{"Architecture is one of man's highest achievements, reflecting the culture of the time". (Paul Rudolph,} 1997)

Culture represents the embodiment of people's world views of the environment and their values, norms, beliefs, and ways of living. In other words, culture is notably the identity, the symbol and the structure (system of transformation) of any society. It is innate in nature, embedded in the minds of societies from the beginning of civilization. Every culture possesses a system to structure an order to their worlds. The system, always perceived as sacred, spiritual and a cognitive evolution of people's world views, has been transformed into physical forms such as dwelling places, the arts and crafts; martial arts instruments and many more.

Religious dimension is another integral part of human culture. It is one of the underlying factors that determine the identity of people and their built environment (Adas, 2001:109). From the beginning, religion was one of the important motivations behind the building of settlement. In relation to the definitions of the term 'cognitive', religion can also be linked with a sense of cognition as it is also relating to or involving the act or process of knowing, including both awareness and judgement. Religion plays a predominant role in shaping the world views and cosmological understandings of the Malay society. It has played an important role over a long period of time in shaping the way of life and component structure. The Islamic faith in the traditional Malay house is reflected in the ornamentations. Muslims are not allowed to install figurines as decorations for their homes, or in the paintings that adorn the walls of their homes. Wood carvings are the common decorations found above the doors and windows of the traditional Malay house. Besides serving as decorative elements, these wood carvings are placed above the doors and windows to allow fresh air to enter and exit the house when the doors and windows are closed. This way the stale air inside the house can be removed and fresh air introduced into the house even if the doors and windows are closed. All of the 
carvings found in the traditional Malay house either have the floral motives or the geometric shapes to observe the guidelines in Islamic decorations.

\subsubsection{The Wood carvings' Symbolism in the Malay Arts and Crafts}

Yahya (1995) wrote about the concept of symbolism in the traditional Malay house in Kelantan, a state in the east coast of Malaysia. He suggested that, "symbols and symbolism have a close relationship with man and his culture". Therefore, the world of culture is a world full of symbols. He also agreed with the view of Ernst Cassirer (Wentzer, 2011) that marks humans as "animal symbolicum", i.e. the animals with symbols. The work of art plays a very significant role in revealing the human's spiritual connection with the Divine concept into a manifest expression of harmony, symmetry, hierarchy and balance. People today, even the Malays themselves seldom understand the meaning behind the 'awan larat' except for its beauty, its uniqueness and perhaps its creativity. This is due to a lack of knowledge of cultural background due to the deteriorating continuity of such creative skills, diminishing the culture of traditional knowledge-transfer through (society) verbal transmission, and also, the lack of exposure or formal education through school programmes or the media and multimedia programmes. Hence, this section has explored aspects of the 'awan larat' and has distilled its significant role in establishing an architectural identity for the housing environment of the local society.

In conclusion the existence of the philosophical elements of 'awan larat not only establishes the characteristics and principles of values, hierarchy (order) and balance in its creation, but more importantly, the same principles or rules also apply to the society in the real, practical world.

\subsubsection{Wood Carvings principles and philosophy}

According to late Wanpo, the philosophy of 'Awan Larat' is a Muslim Malay artisan's method of interpreting and conveying the messages of the Divine Concepts, the positive aspects of Malay community values and the fundamental concept of the reality of the world, besides the obvious reasons for creating beautiful works of arts. As Malay culture and Islam are inseparable, the existence of Islamic philosophy in the Malay woodcraft is a must since the religion only rejects the production of worthless or meaningless designs but not beauty. He adds that the philosophy cannot be seen, but can be felt through the institutional dimension and through this, humans can feel the existence of the Divine Essence. (Azmin, Aida K. (2007).

\subsubsection{Manifestation of the spirit of wood in the traditional Malay houses}

\subsubsection{Selection of wood as craftsmanship material}

The resilience of wood from fungal and powder attacks is an important factor for the carving materials especially for the building components. The traditional Malay house that is aged more than a 100 years are mainly in Kelantan, Terengganu and Negeri Sembilan states of Peninsular Malaysia. The Kampung Laut Mosque in Nilam Puri, Kelantan, was built from Cengal wood 180 years ago and is still standing until now. The wood's colour or shine also become factors of why certain species are chosen by the wood carver. The core of Sena wood is brown and shines when smoothly polished, most suitable for furniture and household equipment. Whilst, Merbau Wood shines when smoothly cut and becomes wood carver's favourite to carve into lattices, roof bowsprit, and headstone. The mystical spiritual belief drives the Malay community to respect the trees and wood, furthermore using it orderly and courteously. The Malay carvers believe in the spirit of wood is the ultimate reason for the particular species selection as a craft component. The spirituality of wood is classified into two aspects, i.e., the physical and meta-physical. For instance, a vintage tree aged more than 200 years old, is believed to be having a keeper among the jinns and satan. So, it is not likely to be chosen as building or carving material. Instead, a wood species like Kemuning, is most suitable for the head of a Keris or badek (Malay daggers). this is because a spiritual wood is appreciated more by the community and makes the particular crafts' carvings ranked high from the Malay people's perception

\section{"Primitive man's primary worldview is of harmony with nature rather than conflict or conquest; the concept of man/ not man in primitive societies is above all one of mutuality" (Rapoport, 1969: 76)}

As a craftsmanship material for housing components, or craft itself, knowledge in wood species selection is essential, based on the convenience to obtain wood resources, component's function, or craft, its physical characters, as well as the wood's resilience and belief in the spirits of the wood. Besides the ability to manifest inspiration into a craftwork, and the skill in wood carvings, the wood carver would examine the factors in tropical wood selection so as to ensure a neat and beautiful craftsmanship product. The intricate assessment process needs a long time that equals the rate of achieving the skill of carving. The physical and metaphysical examinations are done by the Malay craftsmen in order to ensure the high quality of carvings. 


\section{RESEARCH METHODOLOGY}

The purpose of this paper is to extract only the implicit values of traditional Malay architecture from the symbolism of Malay wood carvings craftsmanship. Due to the nature of the inquest, the research applied qualitative enquiry method from literatures reviews; case studies visits observations of several traditional Malay houses across Peninsular Malaysia's states and reviews of measured drawing reports of timber houses from the Centre for the Study of Built Environment in the Malay World (KALAM) at the Department of Architecture in the Universiti Teknologi Malaysia (UTM). Whilst, the open-ended questionnaire and interviews were done face-to-face and through emails and postal mails. The methods had been employed to investigate the norms, values, actions in the art of making wood carvings from the perspectives of experts' and homeowners' respondents, as 'seeing through the eyes of people' and the data that emerged were connected to literature and theories that were 'grounded in reality'.

In order to evaluate the findings the researcher refers to Aspinall and Ujam (1992)'s analysis approach, based on categories: (1) Objects, which are created as a response to the environment; (2) Aspects, which are feelings, preferences, attitudes, perceptions, thoughts, and affection towards the environment, and (3) Activities, which are the behavioral responses towards the environment. This paper focuses on relevant, literature reviews, survey and highlights only two case studies', findings on wood carving symbolism Rumah Tok Jamaliah and Rumah Tok Asiah, in Kedah.

\section{ANALYSIS OF FINDINGS}

This section demonstrates the qualitative descriptive analysis of the findings from both theoretical and empirical studies. The researcher has established the following categories to analyse the significance of wood carvings in the sustainability of contemporary Malay architectural identity, from its physical functions to its symbolic, cosmological and religious implicit meanings.

\subsection{Wood carvings functions in Traditional Malay House Architecture}

Yatim (2001: 343) asserts that the products of the Malay wood carvings are mostly in the form of panels used to decorate the walls of the houses and mosques. He describes the most often used motifs used include the sulur (the tendril), the awan larat (the curvilinear fretwork) and flower motifs such as the lotus flower. The use and choice of the lotus flower is also interesting, for instance, the use of bloomed lotus is used in the houses, which symbolises life and its challenges. A wilted lotus is the motif decorating a gravestone, which carries the meaning that a person has left the ephemeral world, and gone to the eternal world to face the Lord. The Beringin (Banyan) tree or Gunungan brings with it a concept that the diversity of the corporeal world with plants, and with the multi-level spatial places, symbolises the journey to God (Aziz Deraman, 1980: 191). Other motifs used are the tapak badak (rhinoceros foot prints), siku keluang (bat's elbow), the shining sun and so forth (Hamid, Ismail, 1991: 199). Another example of wood carving with a cosmic element is what is called bangau (the stork bird). It is attached to the back of the fishermen's boat on the east coast of the Peninsula Malaysia. To the Malays, the bird represents a cunning way to catch fish [ibid]. Whilst Said, Ismail et al (2002) adds, the head of the stork, called makara is the Pattani-Malay myth about cosmology and the sea.
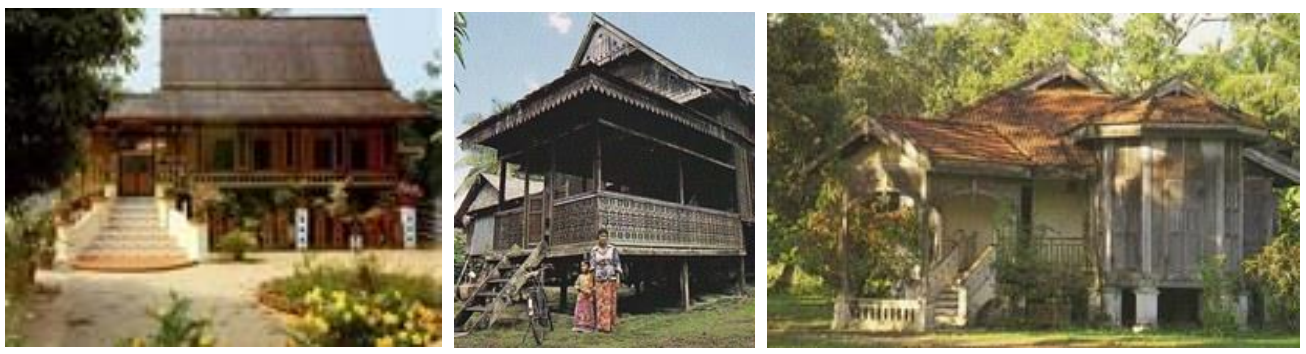

Fig. 1. The dwelling architectures of southern region found in the states of Melaka and Johor.

\subsubsection{Wood Carvings at exterior and interior openings variations for ventilation}

Rosmawati Othman, the director tor at Nik Rashiddin Academy (ANR) of Traditional Malay arts, crafts and architecture, mentions that new housing scheme nowadays are no longer appreciating traditional Malay arts and architecture. For example, from the technological and artistry aspects, including local materials availability the choices are all from the most recent materials. So many generations of designers, architects, even students who are learning about art-related fields, carvings art, and architecture, do not know about the specialty, advantages, and the uniqueness of the traditional Malay dwelling architecture (Aida K, Azmin, 
2007). However, she claims that some individually owned Malay houses do still maintain the traditional elements such as woodcarvings. According to her, the carvings should not be perceived as merely beautiful decorative elements on the building, but one must also understand its underlying function. In her words, "..Since, the first thing is from the aspect of comfort of the in-house occupants, because the carvings are holed, what we call the "Tebuk Tembus" (pierced through carvings) in order to enable the perfect air ventilation. So, if the house during the daytime, night time; hot or rainy weather; when we have to close our windows and everything, the carvings always allows the air to ventilation throughout the house. Apart from the big parts, from windows and doors, but the carvings help in terms of our comfort - from the lowest level (floor), the middle level, or the upper level. If we look, from the floor level, we can see the lowered windows down to the floors. At the middle level, we have the windows that are usually holed whether at the bottom, or carved walls, etc., and at the top level, there is a "Jejala" for ventilation".

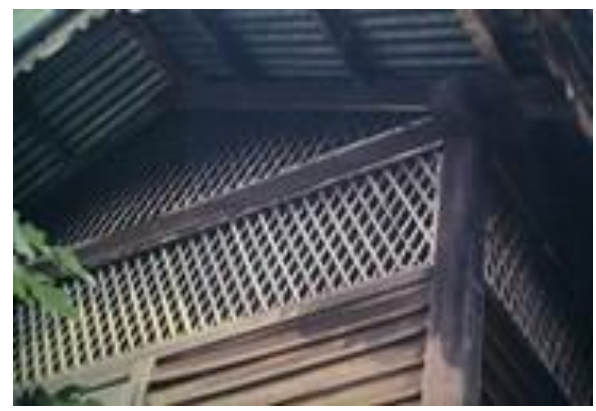

Fig, 1: Woodcarving as 'Jejala' above the wall, below the roof, for ventilation purpose.

The Malay house is also elevated from the ground. When it is raised, evidently, there is always back and forth air ventilation below the house. So the house becomes very comfortable and especially cold during certain seasons. The openings are the most vital elements in the architectural design of the traditional Malay dwellings. They must deal with the hot and humid weather and create a cool and comfortable indoor living environment. Hence, the openings should be able to control daylight into the building, as well as the air ventilation so as to cool the indoor spaces (Azmin, Aida K., 2007). Besides the obvious function of resolving the climactic conditions, the openings' designs should also incorporate the human relationship with nature, and cosmological understanding as shown in the pictures below:

\subsubsection{Wood carvings at exterior openings}
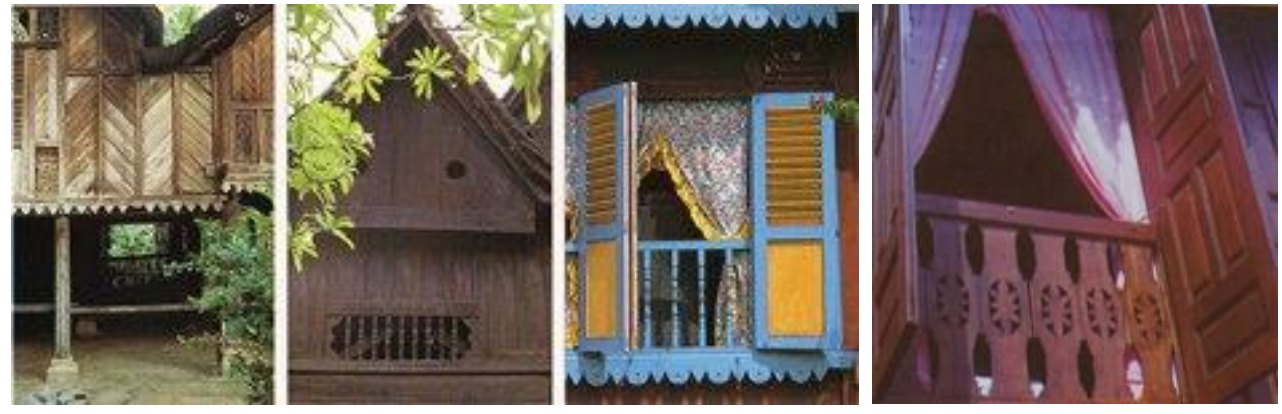

Fig. 2. the variation of external openings with carvings in the traditional Malay house

\subsubsection{Wood carvings at the interior openings}
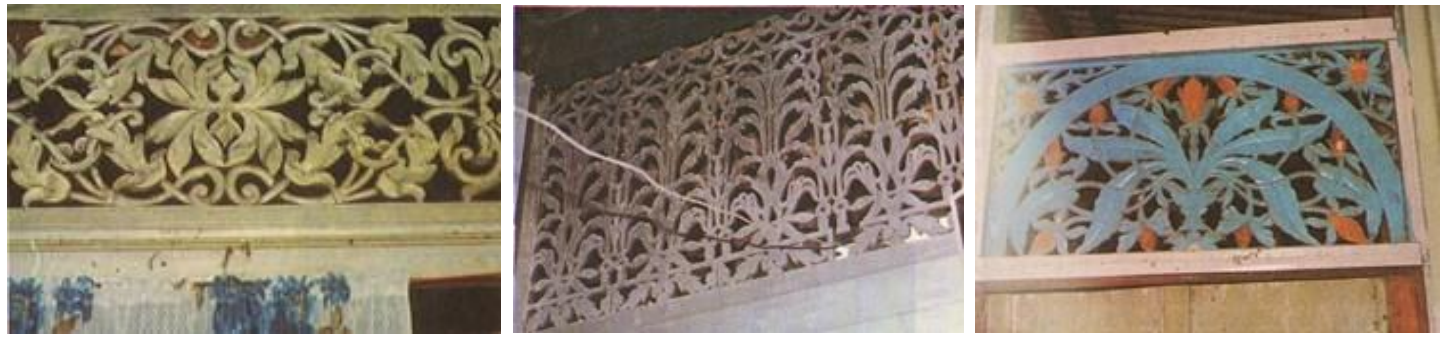

Fig. 3. Above left: Leaf motif above the door; Middle: Pokok Hayat (Hayat plant) motif; Above right: 'Sulur Meliding' another plant motif above the door and on the 'kekipas' functioning as the air ventilators to let hot air pass through the higher part of the house, leaving the cooler air to remain within the house. 


\subsubsection{Other types of Wood Carving as Architectural Decorative Elements}

Mainly, wood carvings as design elements make reference to natural surrounding environments, like the flora and fauna, as well as geometric design inspirations from them, due to the Islamic religious hindrance from depicting actual human and fauna figurines in any three-dimensional works of art. The following figures demonstrate decorative elements of wood carvings of typical traditional Malay houses (Yahya, M. A.,1995), illustrating the Malay designers' interaction with nature, cosmology and indigenous world views, which result in the manifestation of symbolic forms of art reflecting the beauty of nature, and the relationship with God.

\subsubsection{Sesiku}

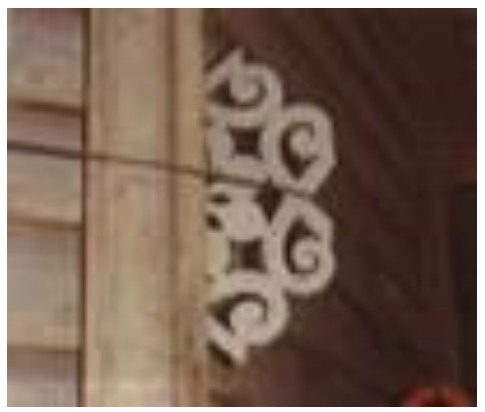

Fig.1: The carving depicts the "sesiku" of a house that derives its idea from the flower and tendril sources

\subsubsection{Floral motif decorations on the ceiling}

The decorative elements in the ceiling are based on floral motifs as shown below:
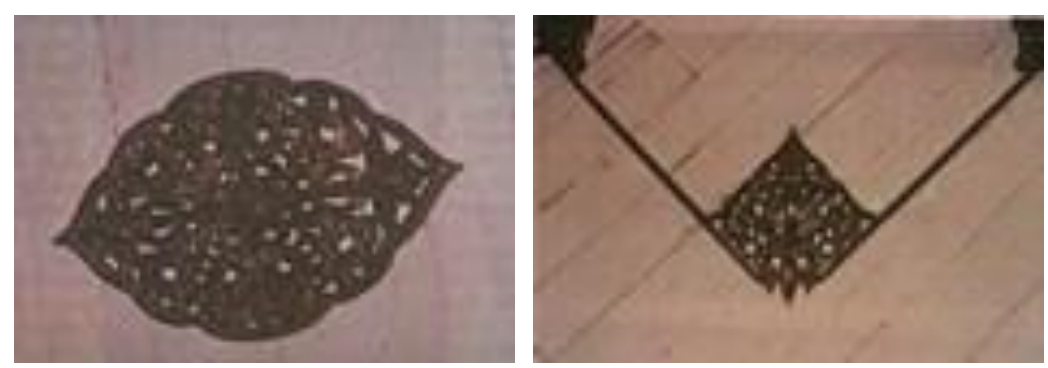

Fig.2: Awan sa'mayang ${ }^{1}$ motif on the ceiling and 'Ketumbit' flower motif on the ceiling

\subsubsection{Geometric motif decorations at Entrance porch}

The Symmetry in nature, reflected in the design of the entrance porch as illustrated below:
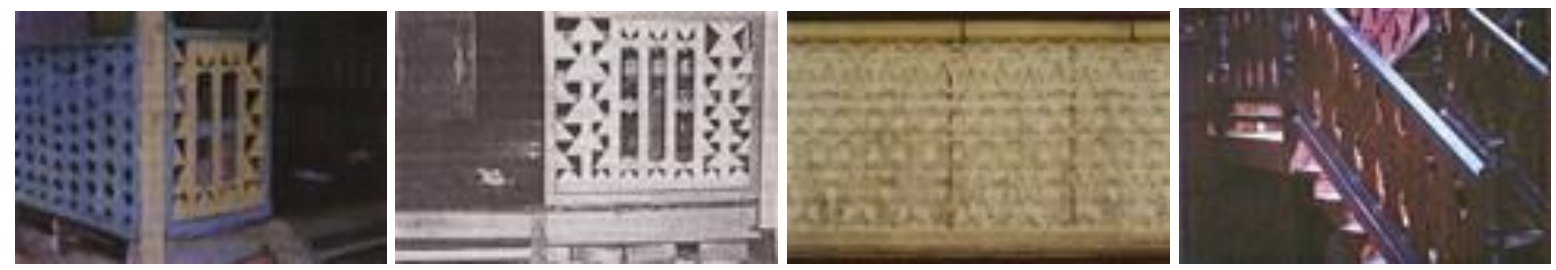

Fig.3: Geometrical shapes motif: Triangle shape motif organised horizontally (first picture) and vertically

(second picture) at the 'anjung' (covered reception area) of the Malay house. The third picture above demonstrates a geometrical shape, combined with flower and plants motifs on the wall of the house.; and the fourth picture shows a floral design motif divided by eight at the 'kekisi ${ }^{2}$ (series of vertical panel supporting the frame) of the staircase.

\footnotetext{
${ }^{1}$ The fretwork that is almost identical to 'awan larat' and is normally concaved.

${ }^{2}$ Alternating panels forming a balustrade for window, or staircase and part of serambi wall.
} 


\subsubsection{Abstract fauna representative carvings at house's external decorations}
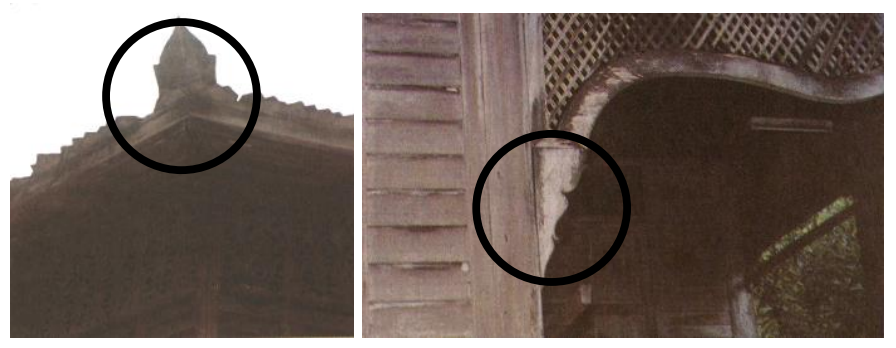

Fig. 4: Above left: End of the roof's pemeles (barge board) shaped like the tail of a duck. Above right: Siku Keluang (bat's elbow) a nickname for the wave shaped motif at the pillar, which functions to strengthen the joint between the pillar and the horizontal beam that support the roof.

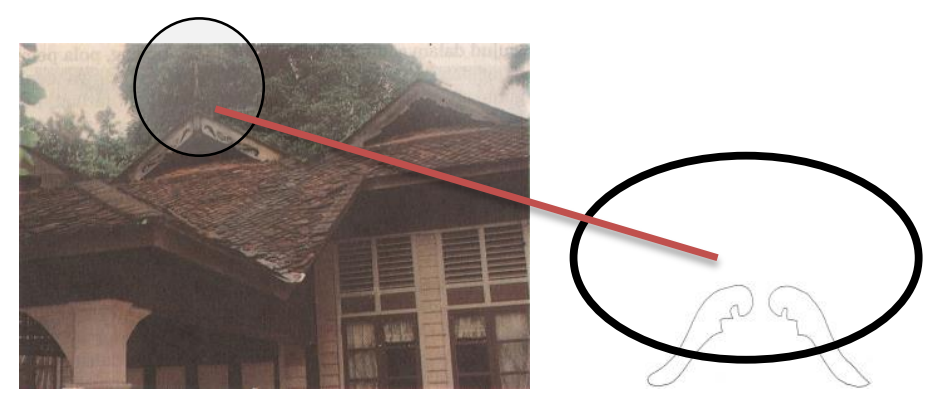

Fig.5: Sea-horse motif at the barge (fascia) boardSub-subsection: Guidelines for References

\subsubsection{Wood Carvings and the Manifestation of "Concept of Unity" in natural lighting}

Osman Bakar (1997: 4) mentions that the idea of 'tawhid' or unity is the most fundamental teaching of Islam. There is first and foremost the unity of God, or to use a more philosophical and scientific expression, the unity of the divine principle. He (God) has many beautiful names and qualities, and yet these constitute a metaphysical unity. This unity is the source of His beauty and majesty. The lighting concept in the traditional Malay house mainly depends on the sun and natural lighting sources. With regard to the concept of unity, Jasmon (1983: 37) explains that Allah's essence encompasses both light and dark aspects; hence there exists a unity within the two situations, either in between external and interior space, or in the spaces inside the house. Rosmawati Othman mentioned that the carvings actually help from the aspect of lighting. When we open the windows, especially in the east-coast region during the hot season, the light is too bright. So, sometimes it makes us feel uncomfortable. When we have walls, it becomes very dark because if the material is 'Chengal', the wall is normally black. So the interior becomes extremely dark. So when we have one side intensely bright, and the other severely dark, our eyes become very uncomfortable. So the function of the carvings is to balance between an area that is too bright and another that is too dark with fascinating holes. That is why when we perceive the carvings, from the aesthetic aspect, during the daytime, it is from the inside-out; and from the night time, it is from the outside-in, because of the silhouette of the carvings (Aida K. Azmin, 2007).

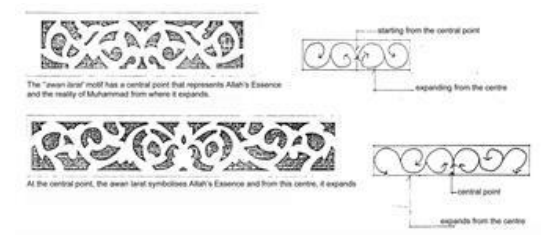

Fig.6: The carving starts from a point in the middle and spreads to the right and left.

Figure 6 above shows the perforated wood carving, which demonstrates the light and dark effect. The essence encompasses both opposing aspects, without limit. Obviously, there exists the unity concept of external space (light) and internal (dark) in the case-study house. The motif of creations in the art of wood carving has an intimate relation with the designers 'beliefs about the concept of Tasawwuf knowledge that may make us appreciate the immensity of the essence of Allah (Jasmon, 1983: 42-43). 


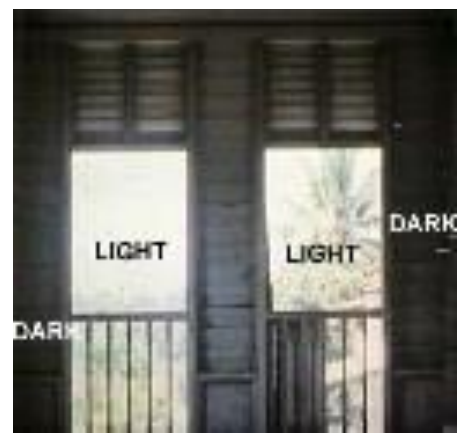

Fig.7: The light and dark effects within a traditional Malay house
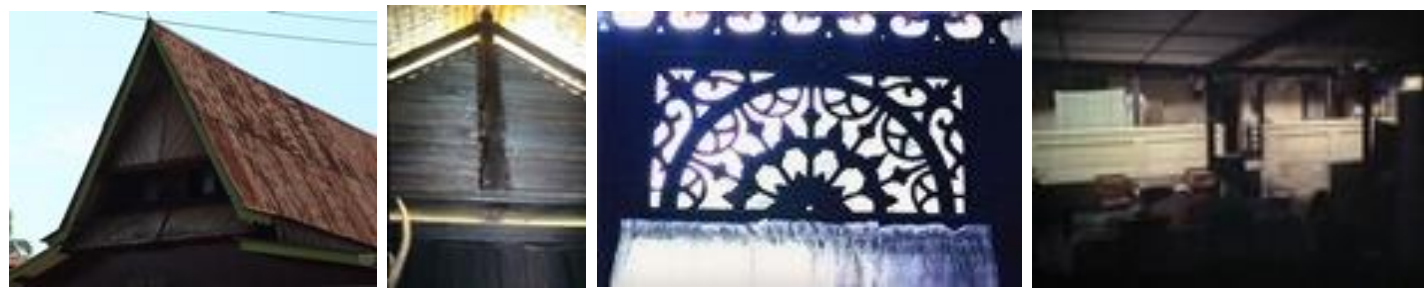

Fig.8: The various openings that allows light to penetrate creating the light and dark effects inside the traditional house.

\subsubsection{Wood Carvings and the Manifestation of "Symbolic Cosmological Understanding (world view)}

Mazumdar (2000: 162) proposes that the views that cultures have of this world, its nature and operation is known as a "worldview". It includes lifestyle, notions of private property, the attitude towards private and public, and neighbour relations. As a comparison, he demonstrates two opposing world views, one of the West's and another, of the East. He calls the former "mastery over nature". It involves finding ways to overcome obstacles presented by nature and thereby, gaining mastery over it. In contrast, the latter, "harmony with nature", is a worldview that seeks harmony and balance. In this view, humans design in ways to achieve balance with nature, not to overpower or harness but to coexist (ibid).

The notion of cosmological understanding and symbolism in the indigenous Malay religious dimension can be described as aspects of faith, belief and spirituality of a person or a community. Table 1, 2 and 3 (refer to Appendixes 1.0 and 2.0) demonstrate the manifestation of symbolic cosmological understanding in floral wood carving motifs and symbolic expressions of religious cosmological understanding in floral motifs and calligraphic wood carving decorations.

\subsubsection{Symbolism in Wood Carving - Curvilinear Fretworks, Decorative Elements: The Art of Engraved Decorations}

Engraving is a traditional heritage used as decoration in indigenous Malay homes, especially for those with high status, or who can afford it. Apart from that, it also serves as unique wind ventilation panels, as well as beautiful sunlight screens. In the past, engravings were the medium of language being interpreted through its practical and visual image. What one can establish from the engraving patterns of the indigenous Malay houses is the difference between two cultural influences - one is Hinduism 15th century, another is the Islamic patterns, based on aspects and philosophies of plants motives, fauna and the embedded meaning in the engravings embraces the principles, feelings, and experiences expressed and delivered by the artisan himself (The Art of Engravings, in Rumah Tok Jamaliah dan Rumah Tok Aishah, Kampung Bubur, Langkawi, Kedah: 100).

\subsubsection{Meanings of the Wood Carvings of Tok Jamaliah's and Tok Aishah's Houses, Kedah}

Table 4 (refer to Appendix 3.0) illustrates variations of woodcarving designs in both houses as in Figures 31 and 32 (refer to Appendix 3.0), which displays a manifestation of the individual owner's identity (and personality) as well as the notion of boundary, between them, although built at the same site, using the same building materials, each house is still different from one another, for example, in terms of the spatial organisation of the houses, and the orientation of each and the aesthetics qualities of the houses, i.e. the wood carvings details. 
It is generally an accepted notion that every individual is different, one from the other. This conception is also a notion of boundary. Hence, this demonstrates the existence of individuality and differences among individuals, manifested in the architectural forms of the respective owners' dwellings. Boundaries or differences are innate in the nature of human existence and it must be recognised and respected. Hence, the dwelling here is indeed a manifest representation of the individual owner's personality, that is, the identity.

\subsubsection{People's Perception and Appreciation of Wood Carvings in Traditional Malay Dwelling Architecture}

Table 5 demonstrates people's perspective and appreciation of the woodcarvings in traditional Malay dwelling architecture: Abdalla (1998) believes that people perceive and appreciate the world in terms of its symbolic sense, meanings and values, but it is quite difficult to separate the form from the symbolic aspects which reflect the cultural attitudes and satisfy the human needs for aesthetics, simply because aesthetic experience is th e result of an interaction between man and his environment (ibid).

\begin{tabular}{|l|c|l|c|c|}
\hline \multicolumn{3}{|c|}{ Table 5: People's Perception and Appreciation of Woodcarvings in traditional Malay dwelling } \\
architecture
\end{tabular}

\section{RESULTS: THE SYNTHESIS OF FINDINGS}

The results synthesize the descriptive analysis into sub-categories of manifestation of Malay craftsmanship symbolism portrayed by the wood carvings to demonstrate the researcher's own discovery on Malay wood craftsmanship symbolism in deciphering Malaysia's authentic architectural identity.

\subsection{Woodcarvings to Embellish Hierarchy of Space and Social Status in Traditional Malay Vernacular House Architecture}

The wood carving motifs indicate the identity of the owner of the house, depicting the homeowner's personality and social status depending on the intricacy of the woodcarving's details as a part of the house's aesthetic as in Figures 33 and 34 (refer to Appendix 4.0). In this case, it is obvious that the owner of this house is a Malay from the floral motifs, both on the external and interior doors, as well as the symmetrical geometrical patterns on the railings. It also makes distinctions between the hierarchies of the spaces. Moreover, the carvings also serve dual-functions for the climatic condition, giving comfortable indoor thermal comfort for the occupants. The nice, beautiful carvings, according to Rosmawati Othman (Aida K. Azmin, 2007) are located at certain spaces/ room only. For example, the "rumah ibu" (mother house), the main domain of the house. So it is the specialty of "rumah Ibu", why is the location, even the name "mother" suggests it hierarchy towards all other rooms in the house. So, when we appreciate its hierarchy, it has been nurtured, taught in an implicit way the honour of a mother, and the important role fo the "rumah ibu". That is 
why we put the most beautiful, most valuable and special things here, and this space is exclusively only for the family.

\subsubsection{Woodcarvings Calligraphy as a Reminder and Owner's Protection in the House}

Rosmawati Othman claims that carvings actually bring some reminders to us about our Creator/God (Allah swt) because these carvings containing Quranic verses, which we hang at certain positions inside the house, act as reminders and always prompts us. That is why we see the calligraphic verses are normally located at the entrance above the door, always praying for the safety of the homeowner, if one reads the verses, this is to avoid any calamities and so forth. So, in this perspective, the occupants would believe that they are always being preyed upon with the presence of the verses. The location of the calligraphic carvings cannot be put at a lower level of anywhere else. It has certain placements and locations. So, that is its speciality. The Quranic verses of wood carvings calligraphy (khat) are all but a combination of meaningful decorations (Aida K. Azmin, 2007).

\subsubsection{Woodcarvings as Identification of "Genius Loci"}

Alexander Pope (1731) debated in his opening remarks for Lord Burlington, in Epistle IV in his writing, entitled, "The Moral Essays", in an analogy between architecture and gardening, everything has to be adaptable to the Genius Loci (the wisdom of the place), and that its beauty is not forced, but borne by it. This notion is similar to the Malay quatrain, "Alam Terkembang Menjadi Guru", which means, the vast universe, becomes the teacher. In Latin, the term, 'Genius Loci' refers to the Genius of a place. Every place and settlement has their own unique identity. not only from its physical revelations, but also from which side it is viewed. Hence, this responsibility is supposedly to be borne by the architect or the designer, to be more sensitive towards the uniqueness of its quality so as to increase its values, not to destroy it. Traditional architecture, despite being labeled as primitive, shall always be the main source in the social and cultural studies by architects and anthropologists. In the Malay world, the traditional principles of building construction were made by the locals in relation to the centuries of transmitted knowledge. Within the local scene, the inevitable art and construction techniques are replaced with modern cities that are oblivious about the prominence and tradition of its Genius loci..

\subsubsection{Woodcarvings as an Expression of Beauty}

Aesthetics itself is an intangible value that cannot be grasped by anyone who has no knowledge of it. In Santayana's (1896, in his first major publication of "The Sense of Beauty") philosophical view, aesthetic is a value, and like all other values, beauty exists only for living creature with particular sense, impulse, and interest. However, the aesthetic element should not finally be abstracted from the practical and moral function of things, the aesthetic may heighten other values, it cannot replace them or render them insignificant. Consequently, an inquiry into aesthetic is concerned with sensibility, with the origin and condition of aesthetic values, with the relation of such values to other aspects of life, and particularly with the nature and elements of our aesthetic judgements (ibid). In this context, the paper suggests aesthetics can be recognized as one of the intrinsic qualities possessed by the indigenous Malay world-views that have been translated into the physical form of arts, architecture and the built environment of the indigenous society. In the context of cultural meaning, aesthetics experience is also based on the cultural experience itself, because culture produces values and symbolism, its physical manifestations are mainly the interplay of symbolic expressions. In this view, the author quotes Altman (1980), "Environmental cognitions are truly psychological in that we interpret the environment and we are selective and incomplete in our portrayal of it. We receive information about the environment from our senses, we process and recognise it in ways that are meaningful to us and to our lives, and the results are represented in and carried about in our minds. What is meaningful, consistent, and appropriate is, of course, heavily influenced by our cultural experience".

The curvilinear fretworks or the 'awan larat' demonstrates whole aspects of the aesthetics experience in the built environment. Hence, it is sensible to say that the existence and continuity of 'awan larat 'fretwork, is vital in the creation of a housing model in the country, not only for its functional purposes as a daylight screen and ventilation instrument, but more imperatively, because of the deeper meanings that the carvings represents for the occupants, the community and the nation as a whole

\section{CONCLUSIONS}

In the fast-paced, robust contemporary living environment, people are faced with the challenge of maintaining their cultural and traditional values. Traditionally, the knowledge of tradition or culture is usually transferred from parents and grandparents to their children, from generation to generation. People may learn about the values and teachings of life from their childhood experience, at home, and through religious and 
cultural upbringing. This way, the continuity of religious, cultural and traditional beliefs of the society are maintained. In contrast, people today build their knowledge and understanding about their own culture through self-interest, sometimes through formal education, i.e. from school and also from social interactions. Other methods of learning include social and mass media platforms on the internet in the age of big-data information technologies; through observation, extensive travelling, as well as life experience - domestic and abroad; exposure to different cultures, and also some guide books distributed among the local community. However, these methods of learning about culture and tradition are very superficial. Inevitably, some valuable information of the culture and tradition may have been lost within the transitional period.

\subsection{Challenges and Opportunities of Malay Wood Craftsmanship Works Sustainability in Achieving The Regional Architectural Identity}

The challenges facing the sustainability of Malay wood carvings in contemporary housing scenario in on the main issue of deteriorating numbers of expert artisans amongst traditional Malay woodcarvers. In the effort to "claim" the "Malaysian's Malay" architectural identity, many stereotypical and similar generic wood craftsmanship are reproduced in local public housing designs, which in fact do not belong to a certain region's identity, nor portraying a correct reflection of the owner's personality. This phenomenon, is due to the lack of sensitivity of the overseas graduated architects, or locally produced architects who are prone to Western ideas and ideologies in the advent of global competition proficiency, and above all, to please the developers in profit-making generation

\subsubsection{Opportunities: Identity: Change and Meanings}

Many scholars find the notion of identity a difficult concept to define. Hewitt (Grant P. (1999) suggests identity can be conceptualized as consisting of three related elements: first, symbolic placement that situates the person in the world, at once differentiating the individual from some aspects of reality and affiliating the person with other aspects. Secondly, an interpretation of both the qualities and values of self-characterized respectively in self-imagery and self-esteem. This multifaceted nature of identity is nicely reflected in the everyday language of identity and identification. We identify ourselves as people of a certain type, quality and value; we also identify ourselves with others and with significant objects, in order to give a sense of belonging and attachment. Thirdly, identities embedded in culture are socially and historically specific. They are produced in the individual consciousness through life-long socialization and the patterned experience of everyday life (Adas, 2001: 27-28). Identity may change with the influence of time. Time is a factor that can add, enrich and transform an individual, a society or a place. In the context of architecture, and the environment, Adas (2001) comments, the place one once knew before may seem rather different when one returns to it a few years later. He adds, objects of the built environment may play a significant role in mediating time and identity, to the extent that they become signs of temporal processes, such as festive decorations, These facilitate the differentiation of time into socially or personally significant units, or act as material symbols of past and future periods (Ibid). He says, "In many cultures, dwellings have been used to symbolise the transition from one life stage to another [...] Houses and dwelling objects are also important to identity in that they constitute symbols from the past, which represent the continuity of a society".

\subsubsection{Preserving Cultural and Traditional Values in Contemporary Dwelling Design}

In order for the contemporary dwelling design to preserve the cultural traditional values, it must first respect the surrounding natural environment. The dwelling design should also relate and incorporate the cultural and traditional values in its concept. These include the symbolic values and cosmological understanding of many aspects of the dwelling design. The dwelling should also be able to accommodate cultural and social needs. Housing developers are urged to have responsible attitudes in their approach towards housing developments, and give their long-term commitment towards their housing projects instead of focusing on profit making. This way, it will ensure the quality of housing construction, as well as the sustainability of the environment. The living environment should be responsive to the local climate and be reflective of local cultural ways of living, instead of imposing foreign or global ideas of what it should be or look like in the modern environment. Modern housing offers ephemeral solutions towards housing demands, but indigenous housing architecture can offer the eternal solutions to a variety of contemporary social and environmental issues, simultaneously sustaining the environment.

The paper has elucidated that wood, as a spiritual building material in traditional Malay houses are symbolically represented by its wood carvings artistry's various types of design elements containing embedded values of principles, supremacy, hierarchy, religiousness, and versatility of its owners. The craft deserves to be regenerated and adopted into the contemporary dwellings and public buildings in search of an authentic Malaysia's regional architectural identity. In recognizing the challenges and opportunities to 
sustain the existence of traditional Malay craftsmanship for contemporary Malaysia's houses and public buildings images, the findings are hoped to be able to outline some strategies for the fulfilment of the topic's main goal.

\section{ACKNOWLEDGEMENT}

This paper is based on the researcher's PhD thesis findings, which were sponsored by JPA and IIUM in 2007. The author would like to thank her co-authors for their enduring moral support in making the article a success.

\section{REFERENCE LIST}

Abdalla, Mohammed Ammar. (1998). Environmental Knowledge and City Perception With a Focus on the Energy Link to Environmental Aesthetics, PhD in Architecture, School of Architectecture, Edinburgh College of Art, Heriot-Watt University: Edinburgh, UK.

Abdul Kadir, Wan., Hashim Awang. (1997), "Seni Dan Kosmologi: Kosmologi Islam Dalam Kesenian Melayu [Trans: Art and Cosmology: Islamic Cosmology in the Malay Arts]" Akademi Pengajian Melayu, Universiti Malaya [Trans: Malay Studies Academy, University Malaya]: Kuala Lumpur

Adas, Yasser Ahmad. (2001). Change in Identity of Saudi's Built Environment: Case Study of Jeddah, PhD in Architecture, School of Architecture, Edinburgh College of Art, Heriot-Watt University: Edinburgh.

Aspinall, Peter; \& Ujam, Faozi. (1992). A Projective Approach to Designing in Children [Landscape Research Journal] (17, no. 3) Landscape Research.

Aziz Deraman, Abd. Rahman Al-Ahmadi, (1980). "Tamadun Melayu: Jilid 2 [Trans: Malay Civilisation: Second Edition]" 2nd); Dewan Bahasa dan Pustaka, Kementerian Pendidikan Malaysia: Kuala Lumpur

Azmin, Aida Kesuma. (2007). A Discourse on Housing Based on Cultural Meanings in Malaysia. PhD Thesis, volume 1 and 2 (2007).

Bakar, Osman. (1997).The Importance of Cosmology in the Cultivation of the Arts ([Wan Abdul Kadir, \&AR, Hashim Awang], "Seni Dan Kosmologi: Kosmology Islam Dalam Kesenian Melayu [Trans: Art and Cosmology: Islamic Cosmology in the Malay Arts]" Malay Studies Academy, University Malaya: Kuala Lumpur.

Bakar, Osman. (2001). Perspektif Kosmologi Tasawuf Dalam Pemikiran Kosmologi Melayu [Trans: "Tasawuf"Cosmological Perspective from the Malay Cosmological Thoughts] ([Harun, Yaacob], "Kosmologi Melayu [Trans: Malay Cosmology]" Malay Studies Academy, University Malaya: Kuala Lumpur, Malaysia.

Fee, Chen Voon.(1998) ,The Encyclopedia of Malaysia: Architecture,, (5 of 15), 1998 1999; Archipelago Press, an imprint of Editions Didier Millet pte Ltd: Singapore

Grant P. (1999) Fables of Identity: John Hewitt and Seamus Heaney. In: Breaking Enmities. Palgrave Macmillan, London. https://doi.org/10.1007/978-1-349-27726-1 2

Hamid, Ismail (1991: 199). (1988) Masyarakat dan Budaya Melayu.[Trans: Society and Culture of the Malays) Kuala Lumpur: Dewan Bahasa dan Pustaka, Kuala Lumpur, Malaysia.

Mazumdar, Sanjoy (2000) People and the Built Environment, Design Professional and the Built Environment [Knox, Paul, \& Ozolins, Peter], John Wiley \& Sons, Ltd.: West Sussex, UK.

Mohamed, Abdullah (1985) Seni Bina Islam, Aplikasi Di Malaysia: Warisan Kelantan Iv, Monograph of the Kelantan State Museum Institution, Perbadanan Muzium Negeri Kelantan [Trans: Kelantan State Museum Institution]: Kota Bharu, Kelantan.

Said, Ismail, \&Adnan, Afira Diwati.(2002). Ciri Pemilihan Kayu Untuk Bahan Ukiran Melayu Di Semenanjung Malaysia (the Criteria of Wood as the Malay Carving Material in the Malay Peninsula) [Housing 
Journal, Building and Planning, Universiti Sains Malaysia] University of Science, Malaysia: USM, Malaysia; .

Said, Ismail (2002) Visual Composition of Malay Woodcarvings in Vernacular Houses of Peninsular Malaysia https://doi.org/10.11113/JT.V37.527 UTM Skudai, Johor, Malaysia.

Jasmon, Hijazi (1983) The Concept of Unity in the Design of Traditional Malay House in Johor According to the Tassawwuf (Unpublished Topical Study, University Technology Malaysia), Architecture and Built Environmen, University Technology Malaysia: Skudai, Joho

Rapoport, Amos. (1982). The Meanings of the Built Environment, Sage Publications: London, UK, Rapoport, Amos (1976, Sociocultural Aspects of Man-Environment Studies ([Rapoport, Amos], "The Mutual Interaction of People and Their Built Environment" Mouton \& Co., The Hague: Paris.

Rapoport, Amos. (1994). Sustainability, Meaning, and Traditional Environments, \{AlSayyed, Nezar\} Traditional Dwelling Settlements Working Papers Series (75); IASTE

Santayana, George (1896 -1902). First published 2003. The Sense of Beauty. Routledge, London, UK. eBook ISBN9780203790793

Wentzer, Thomas Schwarz (2011). An Animal Symbolism and Homo Interrorgans CAssirer's Philosophy of Cultura Between NeoKnatianism and Discursive Anthropology. pages 61-80. Volume 46: Issue 1 https://doi.org/10.1163/24689300 0460105

Yahya, Muhammad Afandi (1995) Simbolisme Dalam Senibina Rumah Melayu: Kelantan [Trans: Simbolism in the Malay House Architecture: Kelantan], Dewan Bahasa dan Pustaka: Kuala LumpurAbdulAziz, Ishak (1979) Seni Bina Masjid Lama [Trans: The Architecture of the Old Mosques], Dewan Budaya: Kuala Lumpur, Malaysia.

Yatim, Othman. (2001). Manifestasi Kosmologi Dalam Seni Halus Melayu (Cosmological Manifestation in the Malay Fine Arts) ([Harun, Yaacob], "Kosmologi Melayu (Malay Cosmology)" Akedemi Pengajian Melayu, Universiti Malaya (Malay Studies Academy, Malaya University): Kuala Lumpur, Malaysia.

Yuan, Lim Jee, (1995) The Traditional Malay House: Rediscovering Malaysia's Indigenous Shelter System. Institut Masyarakat / Central Books Penang,, Malaysia. ISBN No.:9679966046. https://www.amazon.com/Malay-House-Rediscovering-Malaysias-Indigenous/dp/9679966046 


\section{APPENDIX 1.0:}

Table 1: Manifestation of Symbolic Cosmological Understanding (world view) in woodcarvings:

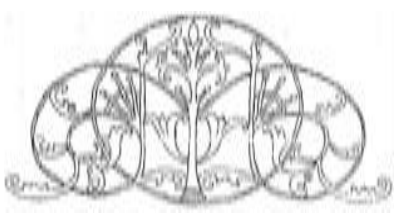

Fig.9: The bean's tendril Fig.10 The carvings tree carvings

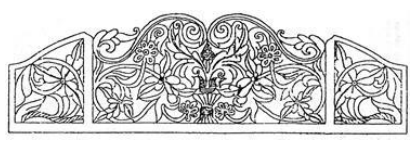
above a staircase's door
Fig.11: The Enclosed Seed. It shows that the seed is enclosed by a leaf until there is no similarity with the visible phenomenal world, without knowing from where it comes, it is the same as the "dot within an idea" in the Western concept.

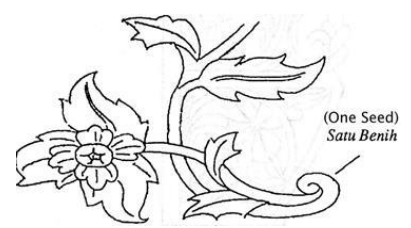

Fig.12 The Manifest Seed.

It shows a manifest that represents the birth of the universe from "One point", according to the West Asian view. From the seed emerges a world divided into two characteristics of 'Jamal '(Divine beauty) and 'Jalal' (Divine majesty)

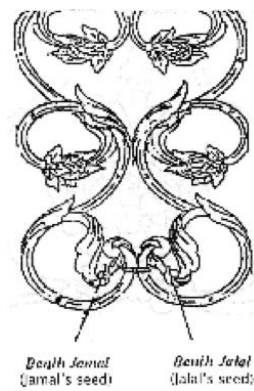

Fig.13: Two Manifest Seeds.

It illustrates two seeds, which symbolise the birth of the world from both divine characteristics of Jamal and Jalal, but which from a vessel. are in harmony that produces such 'exquisiteness'. of a vessel.
Fig.14: Seed in the form

It shows the birth of the world from one seed, which within it contains both divine characteristics
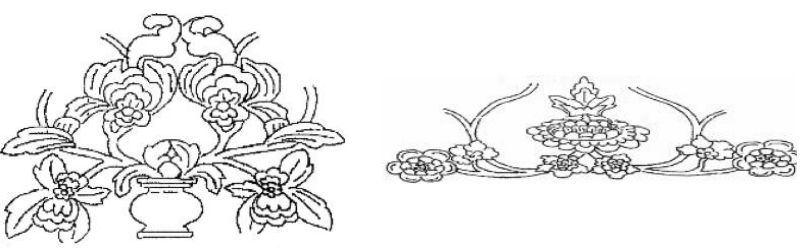

Fig. 15: Seed in the form of a flower.

It demonstrates the birth of the world from the 'Jamal' (Divine beauty) characteristics symbolised by the flower, but within it contains both 'Jamal and 'Jalal' (Divine majesty) delineations that emerge in the manifest world 
APPENDIX 2.0:

Table 2: Expressions of religious cosmological understanding in the floral motifs

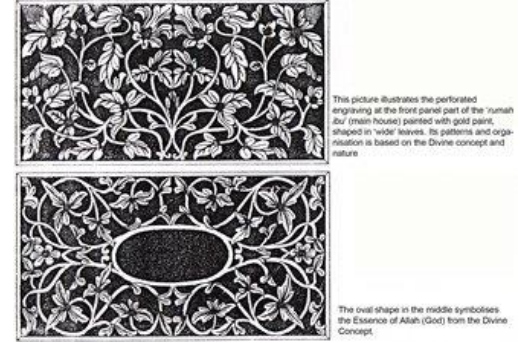

Fig. 16: Cosmology based on the religion as expressed and illustrated in the floral motifs.

The above carving illustrates the perforated flower motif engraving at the front panel with gold paint, shaped in wide leaves. Its patterns and organisation is based on the Divine Concept Unity (Tawhidic) concept. The oval shape at the centre symbolises the the Essence of Allah from the concept.

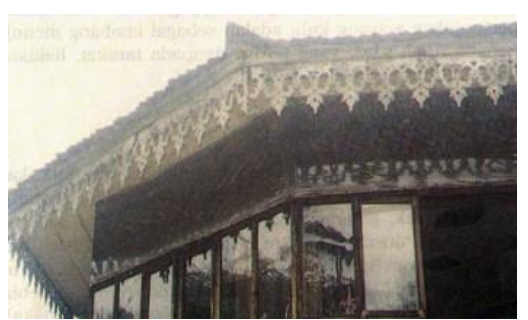

: Fig.17: Above: 'Andam-andam' decoration at the fascia board of the rooftop as a symbol of faith. Figure above is an example of the notion of religious cosmological understanding (world view) in the art of woodcarving and engravings, as interpreted in the 'awan larat' (curvilinear fretwork) design.

Table 3: Expressions of religious cosmological understanding in calligraphic motifs

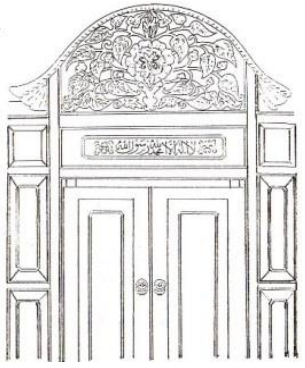

Fig.18: The woodcarving style typically found in the front door of the Kelantanese (people of Kelantan) houses are mainly based on the floral and calligraphic design motifs that portray the symbolic cosmological and religious meanings.
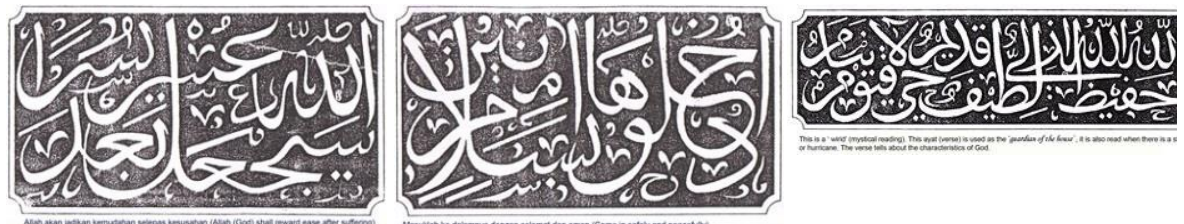

Fig.20: Calligraphic motifs from the Quranic verses and their meanings are common decorateive elements found in the Malay houses

Meaning of the above Meaning of the above This is a 'wirid' (mystical Quranic verse Quranic verse reading. This ayat woodcarving calligraphy: woodcarving calligraphy: (verse) is used as the Allah (swt) Provide ease Come in safely and with difficulties. peacefully 'Guardian of the house'. It also read when theres $\mathrm{i}$ a storm or hurricane. The verse also tells about the characteristics of Allah swt.
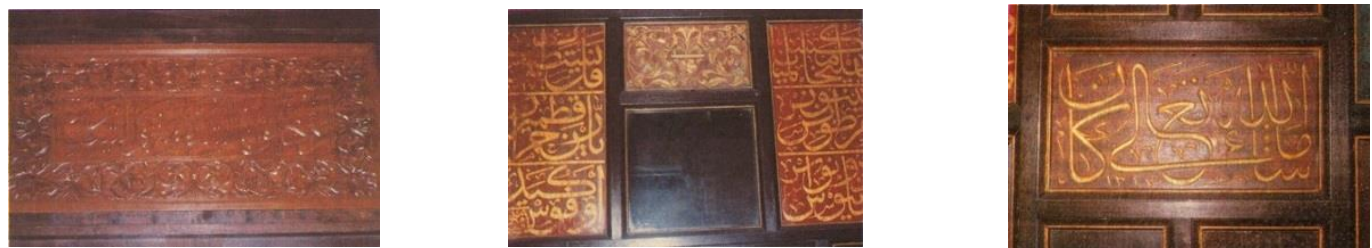
Fig.21: Calligraphy motifs on embossed walls and upper walls. Top left: Calligraphy work containing verses from the Quran on top of the door and on the upper walls (middle picture). The third picture illustrates 'calligraphy motif on the embossed wall. The Calligraphy work containing verses from the Quran on top of the door verses are symbol of religious beliefs and protection for the whole family or dwellers of the house.

\section{APPENDIX 3.0:}

Table 4: Expressions of woodcarvings of Tok Jamaliah's and Tok Aishah's houses, Kedah.

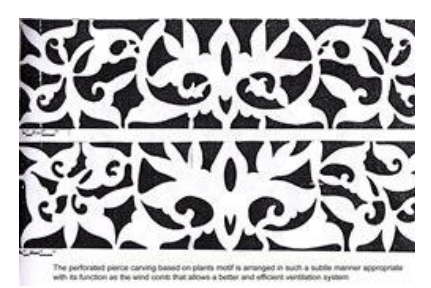

Fig.22: The direct piercing curvilinear fretwork originates from a the floral motifs carving point in the middle and spreads towards right and left, forming a symmetry in the design.

The perforated pierce carving based on plants motif is arranged in such a subtle manner appropriate with its function as the wind comb that allows a better and efficient ventilation system.
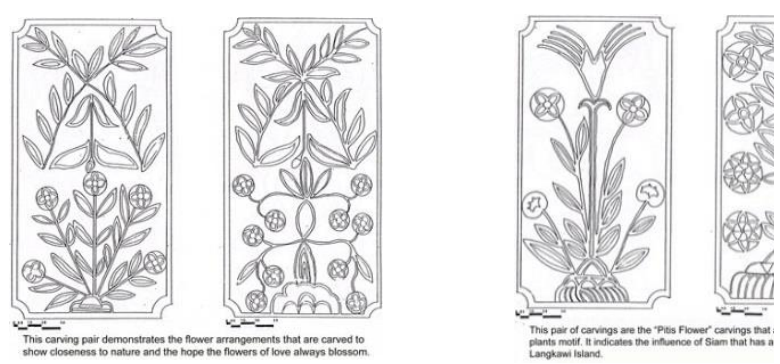
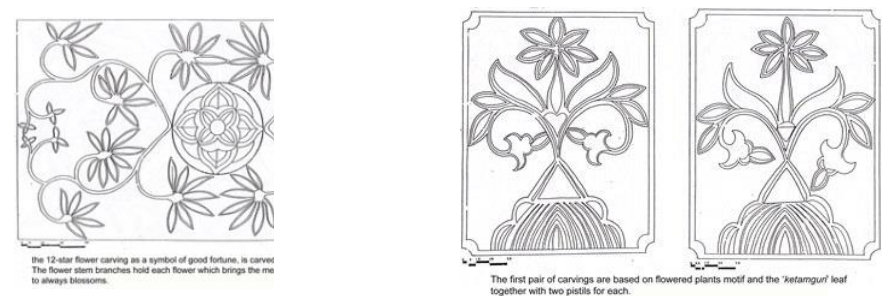

Fig.23: Symbolic meanings illustrated in pattern. The 12-star flower carving as a symbol of good fortune, is carved at the front elevation's wall panel. The flower stem branches hold each flower which brings the meaning of hope for the good fortune to always bloom.
Fig.24: The first pair of carvings are based on flowered plants motif and the 'ketamguri' leaf together with two pistils for each. The unity concept is again used with symmetrical, reflection and repetition principles to enhance the beauty.

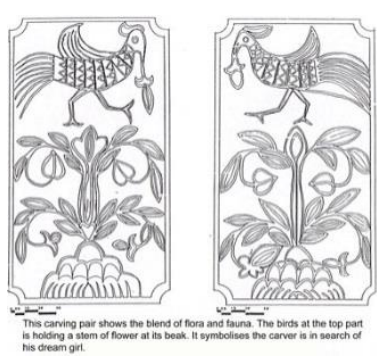


Fig.25: This carving pair demonstrates the flower arrangements that are carved to show closeness to nature and hope the flowers of love always bloom.
Fig. 26: Curvilinear fretwork based on pla motifs with meaning. This pair of carvings are the "Pitis Flower" carvings that are arranged from plants motif. It indicates the influence of Siam (Thailand) that has a strong effect upon Langkawi Island, Kedah.
Fig.25: Curvilinear fretwork based on combination of flora and fauna motifs with meaning.

This carving pair shows the blend of flora and fauna motifs. The birds at the top part is holding a stem of flower at its beak. It symbolises the carver is in search of his dream girl.
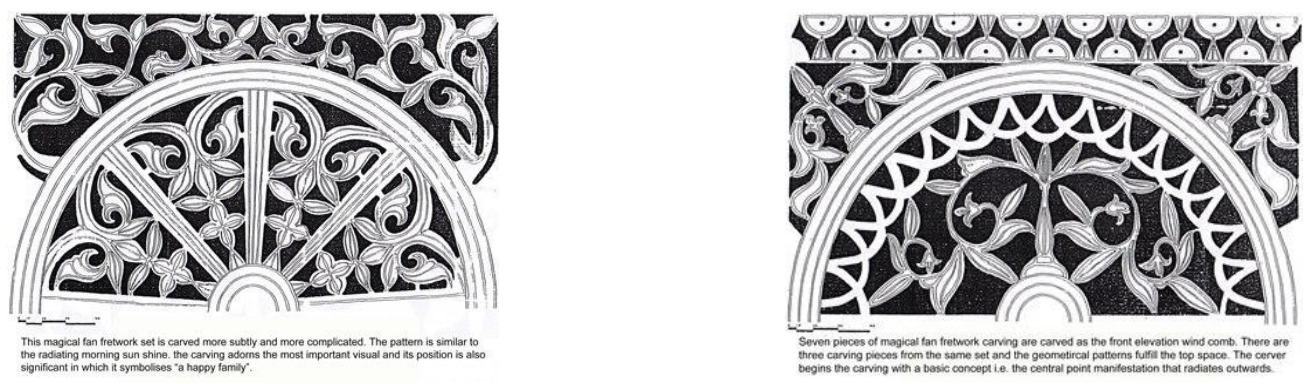

Fig.26: Different styles of "Magical Fan" shaped curvilinear fretworks, with similar functions and different meanings.

Above left: this magical fan fretwork set is carved Above right: Seven pieces of this type of magical more subtly and more complicated. The pattern is fan fretwork carving are carved as the front similar to the radiating morning sun shine. The carving adorns the most important visual and its position is also significant in which it symbolises " a happy family". elevation wind comb. There are three carving pieces from the same set and the geometrical patterns fulfil the top spaces. The carver begins the carving with the same basic concept, i.e., the central point manifestation that radiates outwards.
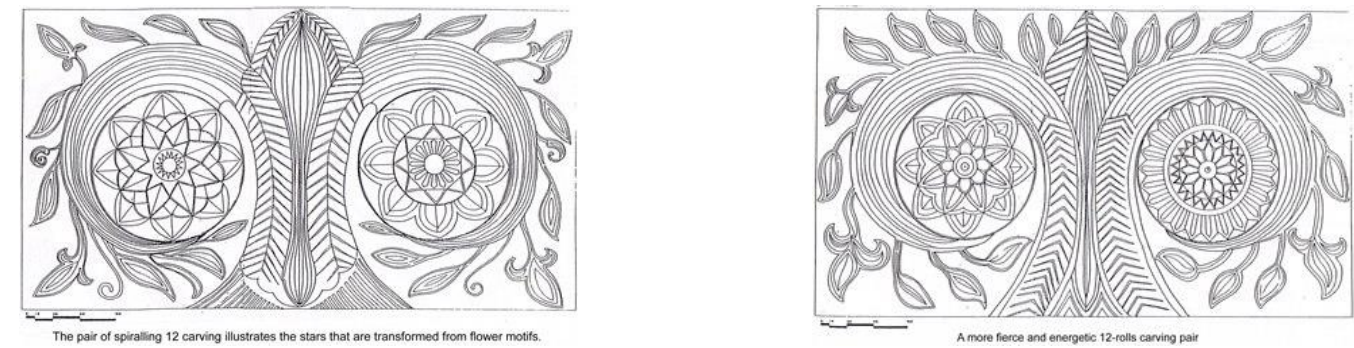

Fig. 27 Spiral curvilinear fretwork designs based on floral and star motifs.

Above left: The pair of spiralling 12 -rolls carvings Above right: A more fierce and energetic 12-rolls illustrate the stars that are transformed fromcarving pair that are also transformed into flower motifs. geometric patterns to show dynamism of energy inside the house. 

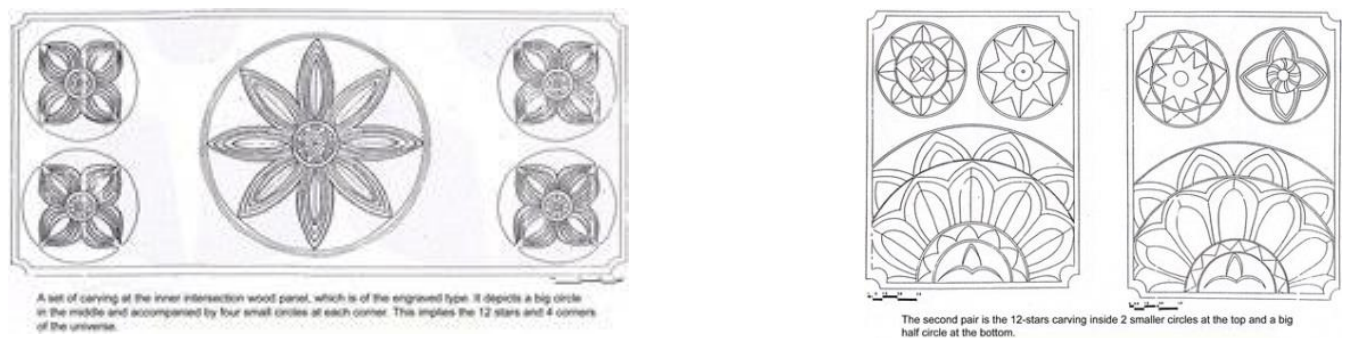

Fig. 28 Curvilinear fretwork designs based on geometrical and the 12 star shapes

Above left: set of carving at the inner intersection The second pair is the 12-stars carvings inside two wood panel, which is of the engraved type. It depicts a big circle in the middle and smaller circles at the top and a big half circle at the accompanied by four small circles at each corner. concept.

This implies that 12-stars and 4-corners of the universe.
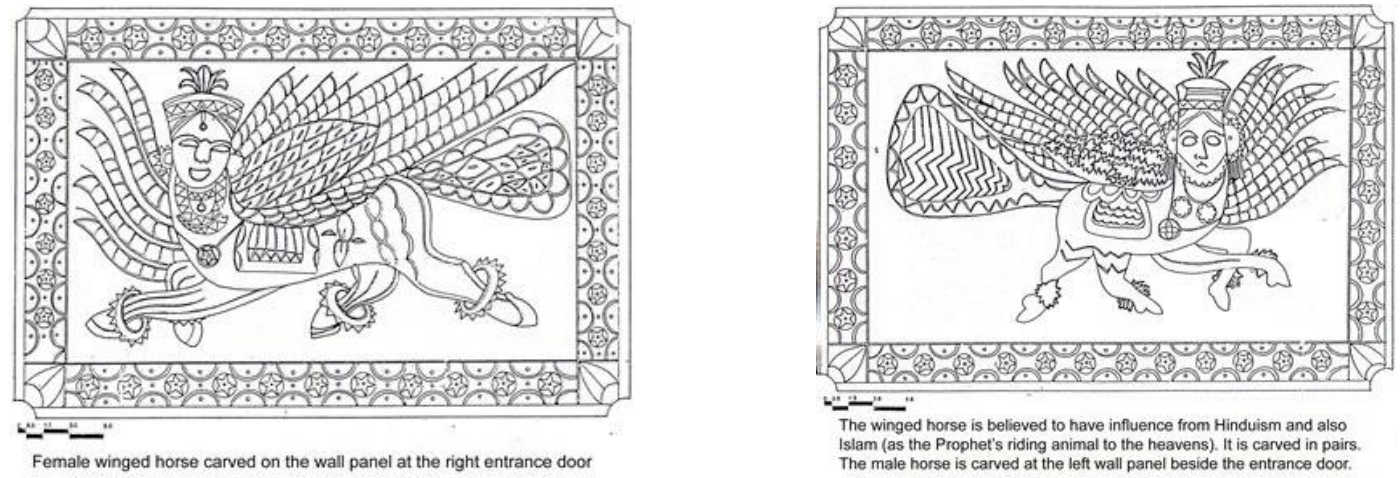

Fig.29: Fauna motifs show religious influence in the fretwork design

Above left: The female horse carved on the wall Above right: The winged horse is believed to have panel at the right entrance door. influence from a mixture of Hinduism and Islamic belief (as Prophet Muhammad's (pbuh) animal ride to the Heavens during Isra' Mi'raj event). It is carved in pairs depicting male and female horse, like in the Hinduism belief. The male horse above is carved at the left wall panel beside the entrance door.
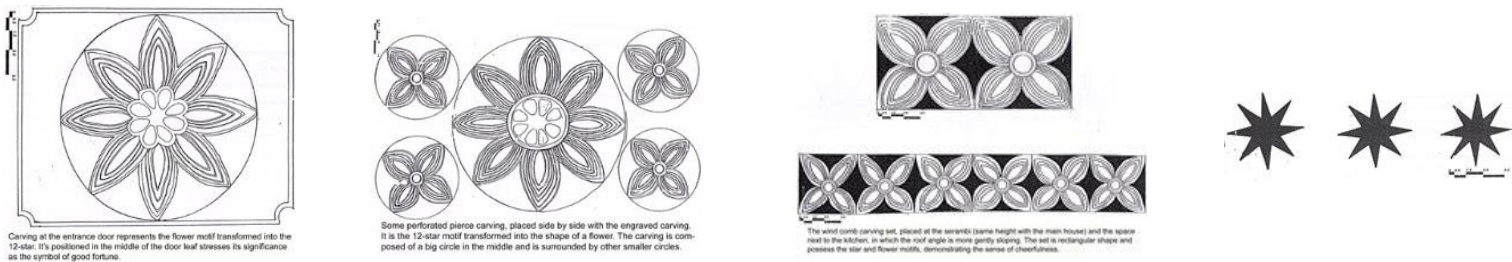

Fig.30: A set of fretwork designs based on the 12 star and geometrical shapes are also found in Tok Aishah's house 
Carving at the entrance door represents the flower motif transformed into the 12-stars. It is positioned in the middle of the door leaf and stresses its significance as the symbol of good fortune.
Some perforated pierce The wind comb carving set, placed at the serambi carvings placed side-by-(same hegiht with the main house) and the space side with the engraved next to the kitchen, in which the roof angle is more carving. It is the 12-start gently sloping. The set is rectangular shape and motif that is transformed possess the star and flower motifs, demonstrating into the shape of a the sense of cheerfulness.

flower. The carving is

composed of a big circle

in the middle and is

surrounded by other smaller circles.
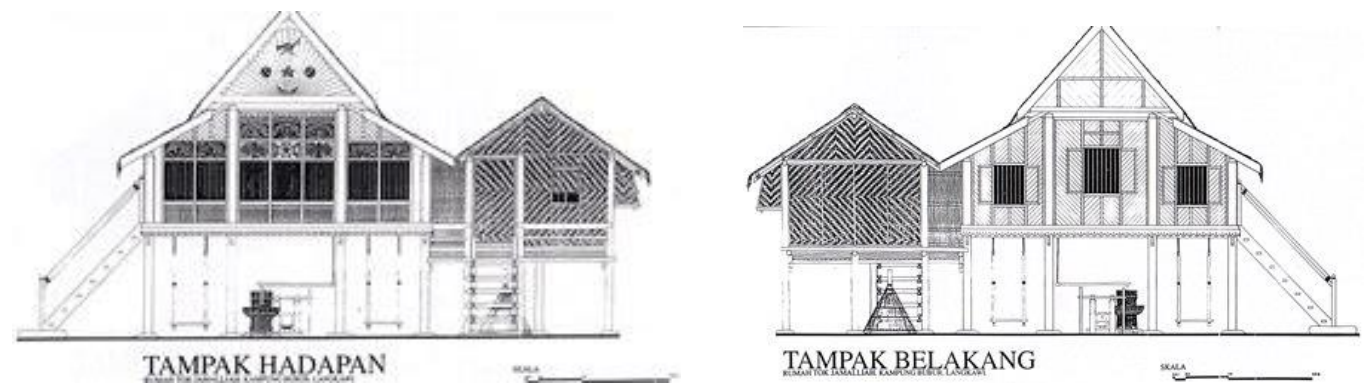

Fig. 31. Architectural drawings of Tok Jamaliah's house in Kedah, showing the identity of its owner.
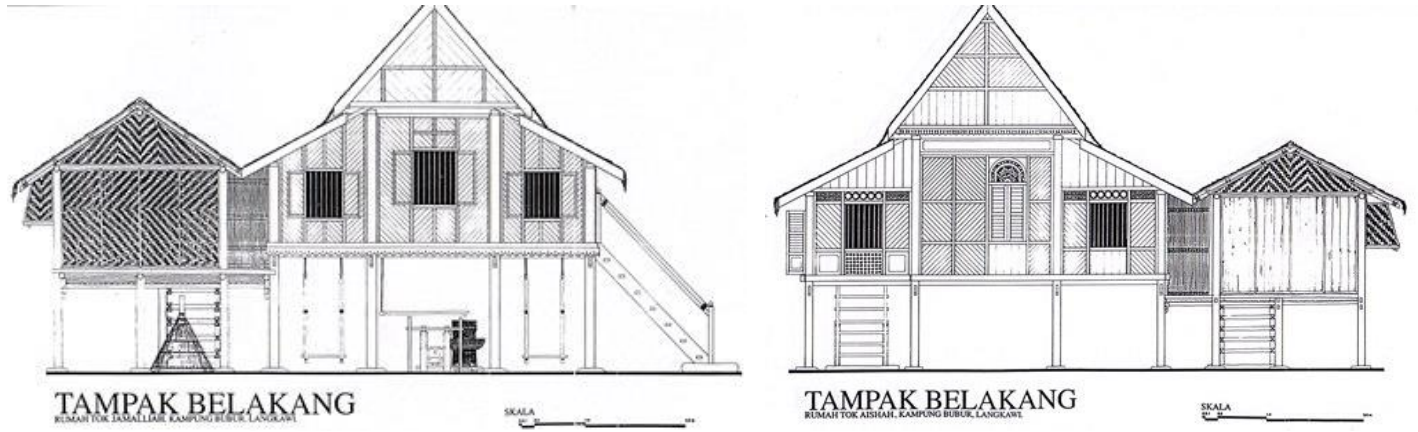

Fig. 32. Architectural drawings Tok Aishah's house in Kedah, showing the identity of its owner.

\section{APPENDIX 4.0}

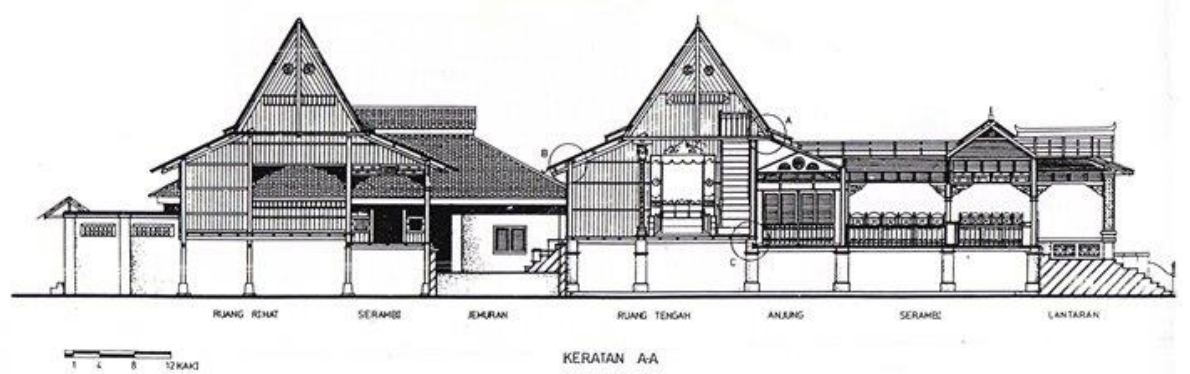




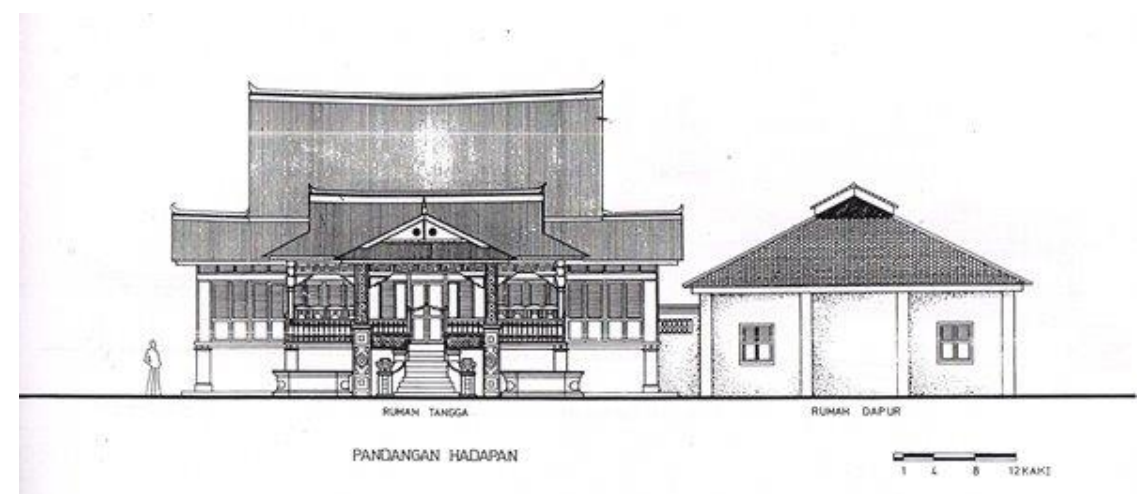

Fig.33 Architectural drawings of Penghulu Mohammad Natar house, in Negeri Sembilan, reflecting the owner's status and identity.

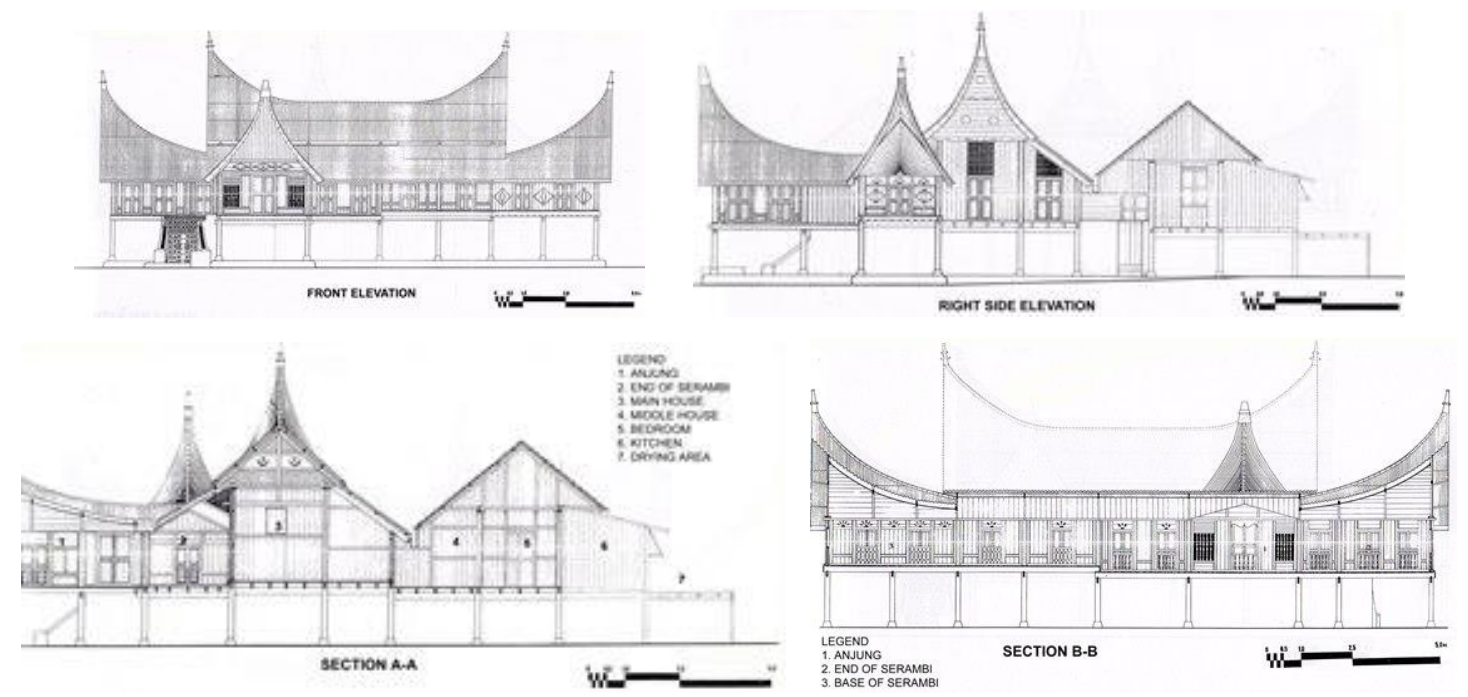

Fig.34 Architectural drawings and plans of Dato Haji Muda Haji Omar's house in Negeri Sembilan, illustrating the owner's status and regional identity. 